\title{
Out of Space
}

Sensory Practices and Placemaking 
PARAGRANA: Als „Kern“ bezeichnet man seit alters auch die Mitte eines Gedankens, als „Körnchen“ auch die Beigabe, die eine Aussage scharf macht wie den Pfeffer, oder feierlich wie den Weihrauch, oder die sie witzig einschränkt, wie das Salz es tut. Das lateinische Wort für beides, granum, war für Paracelsus zugleich die Bezeichnung für ein Mineral- oder ein Erzkörnchen geblieben, das die Natur hergibt, damit der Mensch es zu seiner Heilung oder Läuterung verwende. Aber weil wiederholter Zusatz eines solchen Körnchens Gedanken und Aussagen verfälscht, wie zuviel Einnahme die Arznei zum Gift verdirbt, musste para, das griechische Wort für ,neben“, mit granum verschmolzen werden, um aufzuweisen, wie eine Substanz beschaffen ist, die nur richtig gebraucht werden kann. So überschrieb Paracelsus seine grundsätzlichste Rechtfertigungsschrift: „Das Buch Paragranum“.

PARAGRANA: Kleine Gedankenkörnchen, die neben gewohnten Saaten liegen, soll diese Zeitschrift auflesen und wieder ausstreuen. Denn Schreiber, Herausgeber und Leser wollen vorsorgen, dass die bisherigen Begriffe, Bilder und Perspektiven, in denen der Mensch nach seiner Geschichte und sich selbst, nach seinem Selbst als Kern aller Geschichte zu fragen pflegte, nicht zu viele Antworten vorprägen, die Wiederholungen sind. Wir möchten an begangenen Wegen vorbei eine Richtung finden, die nach rückwärts zu mehr Klarheit führt, wie sehr sich der Mensch verändert hat und wie nicht, und die nach vorwärts ahnen lässt, wie anders er sich innerlich und äußerlich orientieren muss, wenn er weiter eine Geschichte haben soll. 


\section{Paragrana}

Internationale Zeitschrift

für

Historische Anthropologie

herausgegeben vom

Interdisziplinären Zentrum für Historische Anthropologie

Freie Universität Berlin

von

Claudia Benthien, Christiane Brosius, Almut-Barbara Renger, Ludger Schwarte,

Holger Schulze, Matthias Warstat, Jörg Zirfas,

Christoph Wulf (Geschäftsführung)

gegründet von

Gunter Gebauer, Dietmar Kamper, Ingrid Kasten, Dieter Lenzen, Gert Mattenklott, Alexander Schuller, Jürgen Trabant, Konrad Wünsche, Christoph Wulf (geschäftsführend)

Band $28 \cdot 2019 \cdot$ Heft 1

Herausgegeben von

Christiane Brosius und Holger Schulze 
Paragrana ist eine internationale transdisziplinäre Zeitschrift für Historische Anthropologie, die im Interdisziplinären Zentrum für Historische Anthropologie der Freien Universität Berlin herausgegeben wird.

Historische Anthropologie bezeichnet Bemühungen, nach dem Ende der Verbindlichkeit einer abstrakten anthropologischen Norm weiterhin Phänomene und Strukturen des Menschlichen im Spannungsfeld zwischen Geschichte, Humanwissenschaft und Anthropologie-Kritik zu erforschen und für neuartige paradigmatische Fragestellungen fruchtbar zu machen.

\section{Paragrana}

Herausgegeben vom Interdisziplinären Zentrum

für Historische Anthropologie der Freien Universität Berlin.

Geschäftsführender Herausgeber:

Christoph Wulf, Interdisziplinäres Zentrum für Historische Anthropologie, Freie Universität Berlin, Habelschwerdter Allee 45, D-14195 Berlin Telefon: +4930 838-55987

Verlag:

Walter de Gruyter GmbH, Genthiner Straße 13, D-10785 Berlin service@degruyter.com / www.degruyter.com

Bitte richten Sie Ihre Bestellungen an:

HGV Hanseatische Gesellschaft für Verlagsservice mbH, Holzwiesenstr. 2, D-72127 Kusterdingen. Phone: +49-7071-9353-82, Fax +49-7071-9353-93 orders@hgv-online.de www.hgv-online.de

Die Zeitschrift erscheint jährlich mit einem Band in zwei Heften.

Online: $\quad$ Abonnement Institutionen: $€$ [D] 80.00 / US\$ 108.00 / GBP 66.00 Abonnement Einzelkunden: $€$ [D] 49.00 / US\$ 74.00 / GBP 40.00

Print: $\quad$ Abonnement Institutionen: $€[D]$ 80.00 / US\$ 108.00 / GBP 66.00 Abonnement Einzelkunden: $€$ [D] 80.00 / US\$108.00 / GBP 66.00

Print + Online: Abonnement Institutionen: $€$ [D] 92.00 / US\$ 119.00 / GBP 75.00 Abonnement Einzelkunden: $€[$ [D] 88.00 / US\$ 116.00 / GBP 72.00

Einzelheftpreis (Print): 43,00 € (Preise jeweils zuzüglich Versandkosten).

Das Abonnement verlängert sich jeweils um ein weiteres Jahr, falls es nicht 8 Wochen vor Ablauf eines Kalenderjahres gekündigt wird.

ISSN 0938-0116

(C) 2019 Walter de Gruyter 
Wissenschaftlicher Beirat: Birgit Althans, Düsseldorf; Norval Baitello, Sao Paulo; Remo Bodei, Pisa; John Borneman, Princeton; Hongije Chen, Beijing; Fabrizio Desideri, Florenz; Isabel Gil, Lissabon; Zandra Pedraza Gómez, Bogotá; Michael Hagner, Zürich; Ute Huesken, Heidelberg; Yasuo Imai, Tokio; Yi Byung Jun, Busan; Klaus Krüger, Berlin; Niklaus Largier, Berkeley; Reyes Mate, Madrid; Alain Montandon, Clermont-Ferrand; Helga Peskoller, Innsbruck; Jacques Poulain, Paris; Andres-Klaus Runge-Pena, Medellin; Valerij Savchuk, St. Petersburg; Sundar Sarukkai, Bangalore; Shoko Suzuki, Kyoto; Fathi Triki, Tunis; Susan Visvanathan, New Delhi; Bingjun Wang, Beijing; Zhang Zhikun, Beijing.

Paragrana wird als internationale transdisziplinäre Zeitschrift des Interdisziplinären Zentrums für Historische Anthropologie der Freien Universität im Programm des Verlags Walter de Gruyter herausgegeben.

Bisher erschienen:

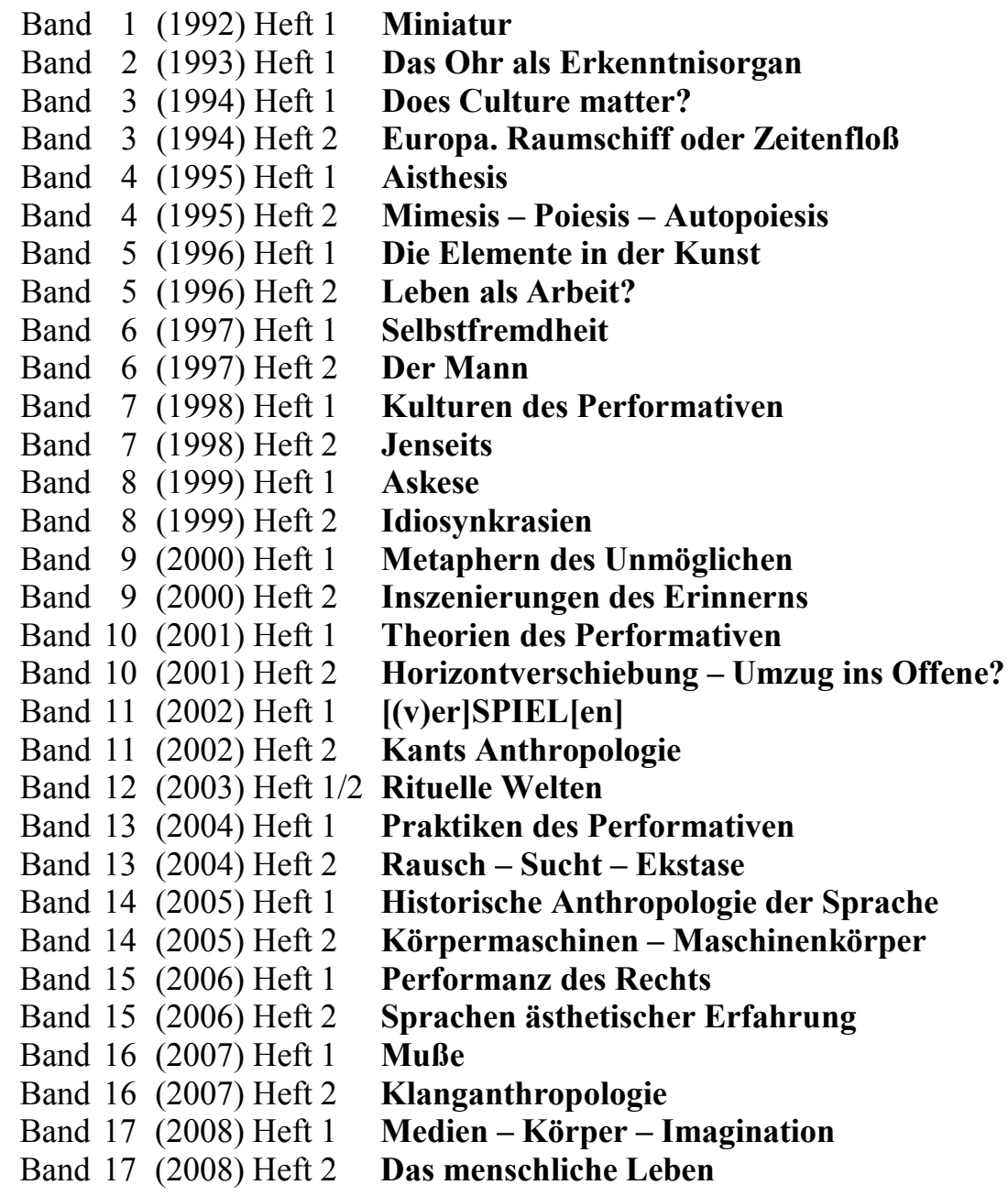


Band 18 (2009) Heft 1

Band 18 (2009) Heft 2

Band 19 (2010) Heft 1

Band 19 (2010) Heft 2

Band 20 (2011) Heft 1

Band 20 (2011) Heft 2

Band 21 (2012) Heft 1

Band 21 (2012) Heft 2

Band 22 (2013) Heft 1

Band 22 (2013) Heft 2

Band 23 (2014) Heft 1

Band 23 (2014) Heft 2

Band 24 (2015) Heft 1

Band 24 (2015) Heft 2

Band 25 (2016) Heft 1

Band 25 (2016) Heft 2

Band 26 (2017) Heft 1

Band 26 (2017) Heft 2

Band 27 (2018) Heft 1

Band 27 (2018) Heft 2

Beiheft 1 (2005)

Beiheft 2 (2006)

Beiheft 3 (2006)

Beiheft 4 (2009)
The Body in India

Handlung und Leidenschaft

Emotion - Bewegung - Körper

Kontaktzonen

Töten

Emotionen in einer transkulturellen Welt

Fuß - Spuren des Menschen

Unverfügbarkeit

Well-being

Meditation

Art and Gesture

Mimesis und kulturelle Metamorphosen

Unsicherheit

Geisteswissenschaften und Gesellschaft

Körperwissen: Transfer und Innovation

F(r)ictions of Art

Ausstellungswert und Musealisierung

Kunst und Alltag

Balance - Rhythmus - Resonanz

Vanitas

\author{
Hand - Schrift - Bild \\ Imagination und Invention \\ Inszeniertes Wissen \\ Konkurrenzkulturen in Europa
}

Die Zeitschrift erscheint mit zwei Heften pro Jahr, wobei die einzelnen Ausgaben als Diskussionsforen mit verschiedenen thematischen Schwerpunkten gedacht sind. Paragrana erscheint in den Sprachen Deutsch, Englisch und Französisch.

Bitte richten Sie alle redaktionellen Anfragen, Anregungen sowie Manuskripte an den geschäftsführenden Herausgeber der Zeitschrift:

Prof. Dr. Christoph Wulf, Interdisziplinäres Zentrum für Historische Anthropologie, Freie Universität Berlin, Habelschwerdter Allee 45, D-14195 Berlin

Telefon: +49 30 838-55701/55987

Mail: christoph.wulf@fu-berlin.de 


\section{Inhalt}

Christiane Brosius and Holger Schulze

Out of Space. An Introduction . . . . . . . . . . . . . . . . . .

Marlène Harles

The Visual Archive as Alternative Place

The Nepal Picture Library . . . . . . . . . . . . . . . . . . . . . . . .

Peter Cusack

On Vogelsang

A Conversation by Holger Schulze with Peter Cusack on his Audio-pieces

Vogelsang Café, Vogelsang Doors and Vogelsang Walk (2017) . . . . . . .

Kaveh Rostamkhani/Cathrine Bublatzky

Iran: Generation Post-Revolution

A Photo-Essay Contextualized

Robert Lemon

Taco Truck Typologies

Underused Urban Spaces as Places for Transcultural Transformations . .

Aida Murtić/Marko Barišić

Unruly Monument: Subverting the Topography of the

Partisan Memorial Cemetery in Mostar . . . . . . . . . . . . . . . . . .

Ludwig Berger/Florian Fischer

On Only Dogs

A Conversation by Christiane Brosius

with Ludwig Berger \& Florian Fischer on their Piece

Only dogs walk as if they know where they're going (2016) _ . . . . . . . . 101

Søren Møller Sørensen

Ruins on Record. Copying Umm Kulthum's al-Atlal, Cairo 2019 . . . . . .

Anna Lerchbaumer/Pia Prantl/Andreas Zißler

The All-Inclusive Soundscape

On the Sound in Three Resorts in Egypt, Tunisia and Turkey . . . . . . . 115

Dikshya Karki

Women as Angry, Muted Subjects in Nepali Films

Navigating ‘Rurban' Space 
Shanti Suki Osman

On Voicing Up

A Conversation by Holger Schulze with Shanti Suki Osman

on her Piece Voicing $U p \ldots \ldots$. . . . . . . . . . . . . . . . . .

Robert Stock

Musik-Filmische Teilhabekonstellationen als Partizipationsversprechen

und situiertes Wissen in The Queen of Silence (2014)

und And-Ek Ghes... (2016) . . . . . . . . . . . . . . . . . . . . . . 153

Andrin Uetz

Spuren der Heterotopie - Hören in Admiralty, Hongkong . . . . . . . . . 175

Sanne Krogh Groth/Kristine Samson

The Audio Paper:

From Situated Practices to Affective Sound Encounters

188

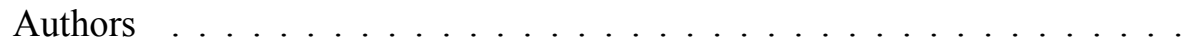




\section{Out of Space. An Introduction}

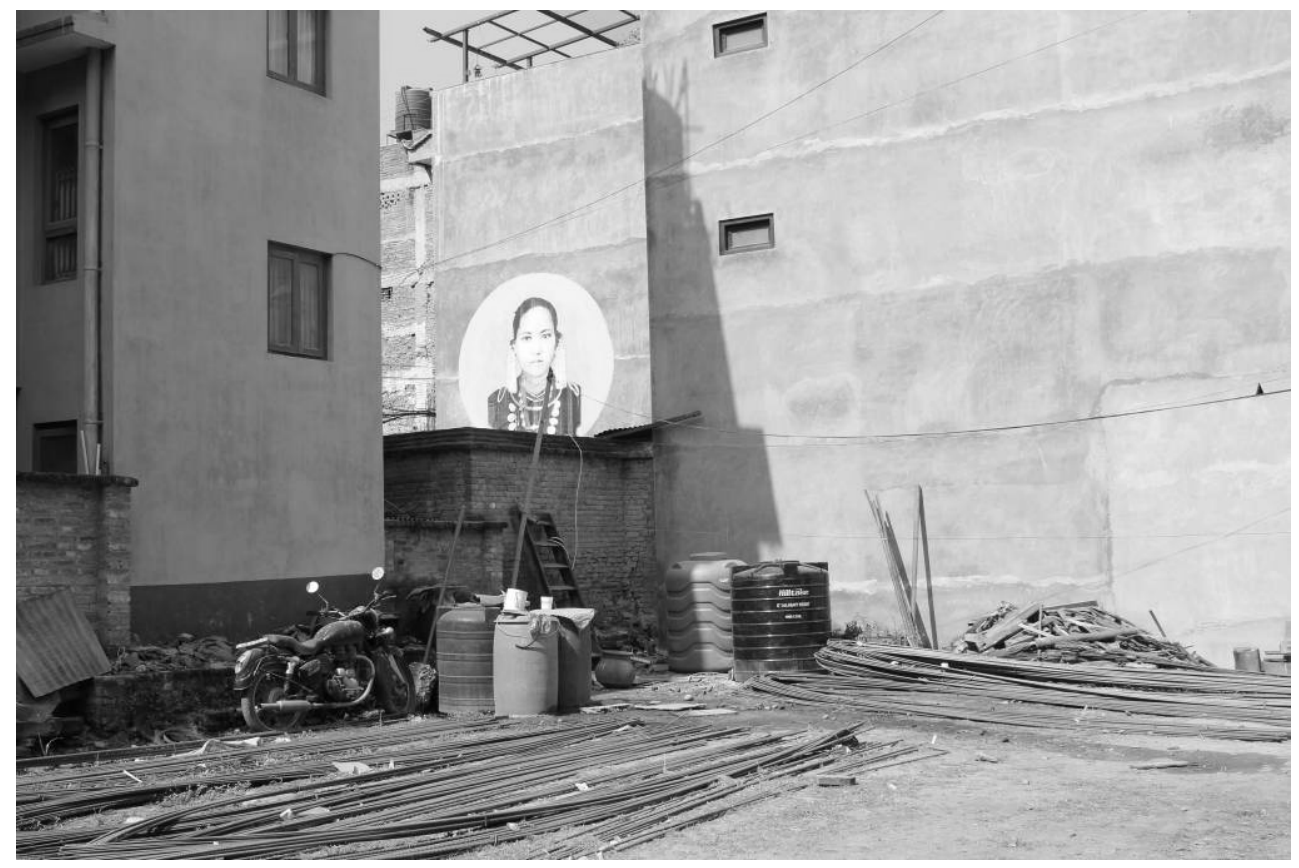

Fig. 1: Portrait of a Newar girl, part of a street art festival in post-earthquake Patan, Nepal (2019, Christiane Brosius)

An academic journal is a special place. On the one hand, it is surely one of the main stages of professional qualification, presentation and academic discourse, though regulated through its gatekeeping structures of peer review, official invitation, of academic critique and corrections: it represents an open and accessible, yet not unregulated public space in the best way thinkable. On the other hand, the individual articles in an academic journal can delve into the most remote, often forgotten, if not illegitimate, informal or ephemeral and intangible issues and practices. Academic articles that explore these areas of the remote, the peripheral and often seemingly inaccessible can then be eye-openers and pioneering explorers: they return to the public space with the gems, the wonders, the newly discovered alien phenomena they found. This special issue of Paragrana might possibly also contain some of these surprises. It was conceived, written, edited and produced from a wide array of physical locations on this planet; besides the research locations of the individual articles that comes from Kathmandu or Hong Kong as well as Braun- 
schweig or Berlin, the editorial work was done in Nepal, Australia, Germany and Denmark.

\section{Where Are We Now?}

Researches in the fields of new cultural inquiries and encounters are not only methodological challenges, which researchers are attempting to overcome and to find convincing solutions for; research in areas such as transcultural, sound, sensory, spatial or eating studies also encounters obstacles regarding the presentation of its material, its argument, and its method. As a result of expanding the empirical and also the anthropological areas of research into the spatial, the transcultural, the sonic, the sensory, or the gustatory, the established presentation formats of academic dissemination reach their limits: how can one present, experiment in, discuss, and scrutinize a spatial, a sonic, a tactile or a gustatory experience - without solely relying on verbal translations, visual or written depictions and transfers? Whereas it remains a major task for researchers in cultural research and anthropology to provide such translations, transfers and interpretations, there is a substantial amount of relevant material that remains excluded from academic presentations and conversations. However, we argue that such material would stimulate academic knowledge exchange and production. Hence, this special issue also considers the ongoing effort in newer areas of cultural and anthropological inquiry to experiment with various new formats of publishing.

The series of articles that we have assembled under the title Out of Space share an interest in approaching placemaking practices by means of trans- and interdisciplinary methods. In this context, the articles seek to trace and make visible or audible these multi-sensorial aspects of shaping places at the fringes or the periphery of what is often coined as 'centre', but also the presence of ephemeral, temporal or interstitial qualities of place that often go unnoticed. The texture of the contributions in this issue is thus a map of niches, islands or foggy areas, often forgotten, banalised or sidelined for various reasons, at specific moments in time. Sometimes this landscape is so rooted in the everyday that one does not pay attention to, for instance, the rhizomic patterns of movement and stillness of informal taco trucks that annotate urban fringes in the USA (Lemon, in this issue). Sometimes it is deeply commercialized and yet 'outworldly' such as thematic holiday resorts and their soundscapes (Lerchbaumer et al., in this issue). There are sites of memory that bring up the 'dark heritage' of civil wars, such as in ex-Yugoslavia, that create interstices and connectivities with the present, and can also be generated by means of certain architectural, ritualized, pedagogical strategies (Murtić/Barišić; Harles, in this issue).

Out of Space also gestures towards placemaking practices that are highly sensorial and/or visual and that require attention but also often interdisciplinary methods to approach and source data in new ways (Howes 2006). Spatial experiences are often multisensorial; memory and imagination play a key role, as does the media 
used in transcending them. This is why this issue has taken up an experimental format, incorporating sound (hosted at an online platform), and paying attention to the location, circulation and fabric of images - be they archived or displayed across various means and to varieties of publics (Rosthamkani/Bublatzky, in this issue). How we sense spaces and our position and mobilities therein also matters when it comes to understanding how communication is practiced, and 'out of space' in this context can be understood metaphorically too, since it is often not 'fixed' in time and space but rather fluid and multidimensional. The liminal character of spatial encounters, the uneven temporality, characterize, for instance, insurgent public spaces such as taco truck drive-ins along highways (Lemon, in this issue) or on parking lots, or backyards and alleyways of a German city during a walk-along (Berger/Fischer, in this issue). The insurgent and interstitial quality of being 'out of space' thus is an approach towards questioning firm geographies and locations and points a finger towards the need to consider the space and speed of movement between 'A' and 'B' as important for an understanding of experience, such as the material dimensions of a street protest in Hong Kong (Uetz, in this issue). Out of Space thus hopes to contribute to another understanding of placemaking practices through sensories, and to the importance of ephemeral or 'pop-up' spaces such as night markets or informal loitering sites for marginalized groups (Karki; Stock, in this issue; see also Mehrotra/Vera 2018). Such discussions can, for instance, be found in new approaches towards "sensorial urbanism" (Zardini 2006). On the other hand, Out of Space also aims to foster a more granulated attention towards sensory practices by means of studying spatial and temporal dimensions in conjunction.

This journal issue explores spaces, peripheral locations, niches and areas that are in at least one respect rejected and abjected, marginalized or tabooed places. We can witness that such sites - be it a parking lot used for performances or timepass, an encroached or abandoned industrial site, or a constantly reinvented and altered memorial site - can be redefined and transformed. In this process, they may well become a culturally and socially 'hip' space or creative hotspot, or even a politically insurgent place through which counter-publics make themselves visible and sociable temporarily. For us, then, 'out of space' is a concept that enables us to explore social experiments, the mobility of thinking about being inside or outside, being included or excluded for varieties of reasons and in diverse ways, of being normal or abnormal, public or private, somewhat liminal and yet entangled. It also challenged us to revise the seemingly fixed binaries such as 'private' and 'public', 'inside' and 'outside', because being 'out of space' is an assemblage of perspectives, localities and scales of connectivity (McCann/Ward 2011).

Finally, Out of Space also draws attention to alternative forms of knowledge production. If we look at peripheries, sideways, and try to grasp intangible contexts with a language that moves beyond quantifiable measuring, then 'out of space' is a site where alternative knowledges can be tested and sustained. Here, our inspiration certainly rests on the fundamental works of earlier scholars such as Henri Lefebvre, Michel de Certeau, Walter Benjamin or Guy Debord and Felix Guattari, to mention 
just a few. We also connect approaches from disciplines such as geography, architecture, anthropology, literature and media studies, urban design, philosophy and sound studies - the youngest contribution to these conjunct realms of thought. 'Out of space' is, we would propose, a good position from which to explore transdisciplinary collaboration and theorizing for today's varied connectivities of people, ideas, things and places.

\section{Mapping Varieties of Being 'Out of Space' and 'In-between'}

The concept of in-between or temporary spaces proves to be key in this context. It cannot just be reduced to temporary space-use ("Zwischenraumnutzung" in German) in a literal, geophysical sense. As a concept, it encourages a view on fluid, precarious, informal, or even occupied or encroached places, on relationalities and boundaries nestled amidst concrete spatial arrangements and forms often taken for granted, attributed with particular and sometimes one-dimensional meaning. The 'in-between' alerts us to a more differentiating, often self-reflexively questioning approach towards the intangible experiences and practices that exist but are often overseen. It is, thus, the look against the grain, the gaze between the clearly readable, the concept as heuristic tool that is of utmost relevance for our collective research effort on urban sensories and sounds, semiotics and imaginaries.

The aim is/was to explore the idea of 'in-between spaces' in these zones as a dynamic repertoire of globality but also possibilities for diversity and alterity that enters the local vocabularies and dynamics of cities, facilitating a transnational rescaling and theoretical repositioning not only of political-economic but also of cultural and social space. Such an approach challenges a centre-periphery model in favour of multicentred networks and rhizomic structures (McCann/Ward 2011). It also considers different fabrics or types of in-between spaces, such as planned and unplanned, informal and formal, temporary and sustainable, materialized and imagined while keeping in mind that like 'public' and 'private' these are fluid and even overlapping qualities rather than stable dichotomies.

Coming from the fields of media anthropology and the anthropology of sound, the editors wondered: What happened to the so-called "Third Spaces" (Bhabha 2004)? When was the last time you indulged in an experience of a "Heterotopia" (Foucault 1997; Burghardt/Zirfas 2019)? How can we grasp the fabric of "NonPlaces" (Augé 1992), or "In-between Places" (Hajer/Reijndorp 2001)? Starting from these moments of wondering and doubt our inquiry began - with a leading question that could be summarized as: "Where are we now?" (Bowie 2013). In 2017, in a collaboration between the Sound Studies Lab at the University of Copenhagen and the Centre for Transcultural Studies at Heidelberg University in the summer of 2017, we invited a number of scholars and researchers from academia and beyond to investigate together with us the aforementioned fabric of being in or moving across the boundaries of 'out of space'. We discovered and discussed then the manifold approaches from sound studies, from sensory ethnography and 
from media anthropology to explore such specific types of generative locations for new socio-cultural practices. We asked: what locations allow for the emergence of new - often erratic - cultural practices? And vice versa: how and when do cultural practices constitute locations, and how do we make sense of this if such creative topographies are deemed as sites of illegitimacy by some? How can we pay adequate attention to 'queer' spaces and how can we shape the conceptual and methodological sensoria that register vernacular, demotic or peripheral fabrics of urbanism? For instance: can we listen to protest spaces of the Umbrella Movement in Hong Kong (Uetz, in this issue)? How legitimate are all-inclusive resorts in countries that are struck with revolutions and economic uncertainty (Lerchbaumer et al., in this issue)? What interstitial locations for courageous artistic performances can we trace archiving practices in contemporary Kathmandu (Harles, in this issue)? What urban void does a taco truck navigate in splintering urbanism and transforming inner cities in the USA; what role does remembering 'authentic' cuisine back in Mexico play in the placemaking practices of the trucks (Lemon, in this issue)? What role does memory play in the context of 'dark heritage' such as Partisan Memorial Cemeteries in Mostar, Bosnia and Herzegovina? Does film function as a means of reflecting new gender roles and spaces of empowerment or exclusion in post-civil war and urban Nepal (Karki, in this issue)?

The articles placed in this special issue of Paragrana mostly evolved out of our conversations at this conference - and in the months afterwards with a wider variety of researchers interested in our endeavour. They shed light on new sensory, visual and gustatory practices in urban spaces; they broaden the realm of art activism, aesthetics and their relevance for vernacular space-making; and they explore contemporary border regimes on fringes, frontiers and nodal points of societies. They constitute an assemblage of research on sounds, tastes and images, their sensoria, imagery, resonances and spatialities. They require then also different critical and self-reflexive Denkräume (Aby Warburg) or thinking spaces. We chose therefore to invite not only contributions that present an argument mainly through a verbal argument, maybe documented with selected illustrations, audio footage or video snippets; but also those which took on more experimental explorations of thought and matter, mainly relying on recorded visual and sonic documents. This sensorial Denkraum, transcending the logocentric into the corporeal, allowed apparently to delve into radically different areas of inquiry.

This issue brings together sound studies, sensory ethnography and media anthropology and explores questions such as these: How can we make sense of public, private, ephemeral and other forms of space and place as we bring together case studies that share a high degree of transcultural traffic? What are the challenges of comparison here, the surplus value of thinking and exploring transcultural placemaking (Hou 2012, 2010)? We have chosen to assemble contributions that range from 'classic' papers to more experimental explorations of thought and matter, such as audio papers or visual essays. We have also included interviews with some scholars who preferred the format of a conversation about their sonic work (Cusack; Osman; Berger/Fischer, all in this issue). And we collaborate with the 
academic and peer-reviewed journal Seismograf, where the audio files relating to some of our contributions will be stored and accessible (http://seismograf.org/ fokus/out-of-space).

\section{Sonic Knowledge Production: The Format of the Audio Paper}

The spatial aspects of sound practices and sound cultures have been an ongoing issue in the field of sound studies, whether in the field of aural architecture (Blesser/ Salter 2006), in techniques of 3D-spatialization of sound reproduction or - probably the longest ongoing research focus - in researching the different sonic environments in the public sphere in urban and rural areas, often under the concept of the Soundscape (Schafer 1977; Järviluoma et al. 2009; LaBelle 2010). The methods, core concepts and approaches in sound studies have allowed for research that studied and studies the history of spatial relations through sound and hearing as well as the spatial arrangement manifest in sound events and sonic traces. Still, these fundamental research efforts mostly seem to confine themselves to documenting, to mapping, to analyzing, and to reconstructing existing sound environments. Hence, research focused on understanding existing spatial constellations and their sonic resonances, their sensory effects, their corporeal embodiments as well as their damaging results on people living and working in certain environments. In the scholarly debates of sound studies, the issues of romanticizing the natural sphere is as much being discussed as a more recent passionate focus on the joys and excitement as well as the generative quality of the urban spheres of transcultural encounters. What research has nevertheless sidelined is explorations of how new sonic environments and their new practices evolve in relation to their sensory environments. Thus, we ask: How can new sonic practices emerge in such areas, and how do certain 'habitats' provide the ground for developing new cultural and sonic practices on the basis of their informality and illegality?

This issue of Paragrana introduces and works with a new academic format: the audio paper. It was developed, experimentally tested and promoted by Kristine Samson and Sanne Krogh Groth (2016), who we therefore also invited to contribute to this issue. The format of the audio paper answers the need in the areas of sound studies, but also of sensory ethnography, of media or sensory anthropology and many others, to present a research outcome that does not solely rely on a written argument and quotable or reprintable text or image sources. A sound environment, individual sound practices, vocal and noise performances as well as auditory dispositives can be investigated and presented by means of the format of an audio paper. Within this issue, we present all in all five audio papers. Some of the contributions follow the audio paper guidelines more strictly (Berger/Fischer; Lerchbaumer et al.), others are presenting field recordings (Uetz), some qualify even as a sound art piece (Cusack), and some find their space in between an audio paper and a radio feature (Osman). 
So, what are the main criteria as to whether a paper is an audio paper in the narrower sense or not? In their Manifesto and in their ongoing scholarly work of refining the use and the aspects defining an audio paper, Kristine Samson and Sanne Groth focus primarily on two aspects: a) an audio paper in the narrower sense needs to propose, discuss and represent an argument in its sound production, and b) an audio paper in the narrower sense necessarily is situated in an academic discourse with specific references, literature and even a bibliography supporting its argument. The contributions to this issue of Paragrana gravitate around this precise definition; they explore it, dismiss it, or find their own, rather idiosyncratic positions.

Because the printed journal of Paragrana does not allow us to play an audio or video file on its paper pages, we decided to collaborate with an academic and peerreviewed online journal with great experience with regard to audio papers. Based in Copenhagen, Seismograf provides a webpage where you, the reader, can indulge into all the audio and video files connected to the chapters and conversations you can read here: http://seismograf.org/fokus/out-of-space. One chapter, at the end of this issue, will also lay out the brief history and the potential of this new academic format (Groth/Samson). We hope that this final chapter will inspire you and other researchers as well as organizers of conferences and workshops to further work with the audio paper as a format for academic presentations: a format that is at the same time experimental, sensorial, and audile, and fits into the well-established formats of academic conferences, peer review-processes, and evaluations.

\section{Mapping the Out of Space: Thirteen Investigations}

Anthropologist Marlène Harles focusses on the Nepal Picture Library, a digital photo archive run by Photo.Circle in Kathmandu, Nepal, since 2011. The chapter strives to create a broad and inclusive visual archive of Nepali social and cultural history, and thus also constitute and institutionalise an alternative repository of everyday and subaltern visual cultures and memories. This is crucial in the light of previous rather top-down and government- (or monarchy-) based initiatives of history and knowledge production. The chapter proposes that the archive constitutes an alternative space - a so-called 'thirdspace'. By encouraging individuals to donate their private collections, Photo.Circle has managed to compile more than 60,000 photographs, many of which are increasingly being made accessible to the public in digital but also exhibition-based forms. Harles explores how the personal and intimate context in which most of these photographs were taken enables the archive to tell visual stories that diverge from, question, or complement the narratives propagated by commercial media, development agencies, NGOs, the tourism industry, or government bodies.

Another kind of 'out-of-space' public archive, half-forgotten and abandoned, is Vogelsang, a former Soviet military ruin $60 \mathrm{~km}$ outside of Berlin, in Brandenburg. Around 15,000 Soviet soldiers from the $25^{\text {th }}$ tank division lived here until 1994, 
where missiles were secretly stationed as well. The ruined city in the forest is a ghostly 'in-between'-space that has somewhat fallen out of time and place, and where excavations of sound (and image) have been undertaken by the sound artist Peter Cusack. In this issue, he talks to Holger Schulze about how the abandoned area of the Soviet army in Vogelsang - a part of the town of Zehdenick in Brandenburg - actually does serve as a rather illegitimate location that indeed fosters new cultural practices, especially sonic ones (an audio and a video file of this piece are accessible on our page at Seismograf: http://seismograf.org/fokus/out-of-space).

Photographs and photographic practices can also be understood as moments of intervention and rupture in times of change and are able to bring to the fore what is often sidelined by official and mainstream media and narratives. One such example are the photographic artworks of Kaveh Rostamkhani. Rostamkhani lives in Berlin and Tehran, his photographs reflecting a deep intimate connection with interstitial, informal, silent spaces that exist in urban Iran, despite sanctions, censorship, and state control. His attention to spaces of leisure and socializing, and to romance and consumption are sensitive traces of life beyond the official screen of the Iranian post-revolution young middle class. In "Iran: Generation Post-Revolution A PhotoEssay", Kaveh Rostamkhani and anthropologist Cathrine Bublatzky bring together the professional backgrounds and the personal experiences of a documentary photographer and a cultural anthropologist in discussing the challenges and ambiguities of visual representation and stereotypes.

Informal topographies of food infrastructures in urban peripheries can also be seen as being 'Out of Space'. Robert Lemon, geographer and filmmaker, presents and discusses in his chapter "Taco Truck Typologies: Underused Urban Spaces as Places for Transcultural Transformations" the role a fundamental tool for streetfood culture can play in the ongoing processes of urban resignification, empowerment, and the bridging of social differences. In homogenizing global cities designed primarily for consumption, informal immigrant practices often challenge the existing community's notion of contemporary urbanism. The traditional taco truck is one such example of a transcultural practice that reappropriates urban space. Paradoxically, heterogeneity is produced through homogenizing forces. Mexicans migrate to the United States for work. Their labor sustains the production of consumer goods. And they bring with them their street food practices. In the US, some of their practices emerge through taco trucks. This paper investigates how the taco truck reorients void public urban spaces in the USA.

Post-socialist and post-war countries often have an ambivalent relationship to remembering war, violence, and trauma. Europe is full of such sites, and in this article, the role of a Partisan Memorial Cemetery in Mostar, Bosnia and Herzegovina is discussed by two authors from the region. In "Unruly Monument: Subverting the Topography of the Partisan Memorial Cemetery in Mostar", Aida Murtić and Marko Barišić write about multiscalar navigations and engagements with multiple histories and the ways in which these historic temporalities spill over into the present, where they are fixed, domesticated, altered and performed, but also ruptured through a whole series of simultaneously, often tension-loaded interventions. 'Out 
of space', in this context, can also be a highly liminal, ritualized, 'outsourced' form of bringing the past to the living generations, and yet also distancing it spatially and rhetorically. The two authors unpack the multi-layered history of the site, unravel the 'unruly' nature of it, despite its normative 'dominant' character, and also show how remembering and placemaking are closely and subtly connected in an ever-changing relationship that disturbs, disrupts, and shapes odd synchronicities of 'reading' and making time, whilst creatively engaging and even calling for civil participation.

The audio piece "Only dogs walk as if they know where they are going" can be listened to on the webpage of our collaboration partner Seismograf; for this issue of Paragrana Christiane Brosius talked with both artists, Ludwig Berger and Florian Fischer, about aspects of their work in relation to locations and practices. The artists have curated an audio walk through the German city of Braunschweig that connects different marginalized places such as abandoned shopping arcades, parking lots or store rooms. The underlining intention was to use sound to bring these places to the fore, to give them a sensorial, embodied fabric, to encourage listeners to pay attention to the 'voice' of sites. The place-making capacities of imagination, paired with spatial experiences, facilitate another kind of engagement into the ways we perceive of a city, of spatial importance, if not hierarchies. 'Out of space' here also refers to the 'elsewheres' and proximities that could be included in our reflections of 'taking place' (see audio file of this piece on our page at Seismograf: http:// seismograf.org/fokus/out-of-space).

The musicologist Søren Møller Sørensen presents in his chapter "Ruins on Record" how a crucial work of Egypt's recording history is being reenacted and revitalised in contemporary recordings and productions - yet this reenactment can, surprisingly, at the same time represent a form of conservative preservation and playful presence. This contribution allows for us to contemplate at the same time the advancement of production techniques and recording practices as well as the mediated intimacies inherent in audio recordings and their stagings.

In "The All-Inclusive Soundscape", video and sound artist Anna Lerchbaumer, together with architect Pia Prantl and architect and media artist Andreas Zißler document, compare and discuss the surprising and partly unsettling aspects of three different holiday resorts that serve as getaways and recreational enclaves. The underlying research aims to explore the auditory daily routine of all-inclusive resorts as a stand-alone microcosm in politically unstable and insecure countries, in this case in Egypt, Tunisia and Turkey. Three comparable hotels were chosen in order to examine the touristic 'bubble' from inside. Sound, it seems, is the oil that keeps the holiday machine running. The article is a reflection about how recorded extracts of the project shape the scheduled acoustic territory of the visited places. Even when there are only a few guests, the background music communicates a similar program and atmosphere in the resorts. The three hotels investigated follow a globalized scheme that can also be found in shopping malls, at so-called "nonplaces'. The strangeness of these resorts, all too familiar for a middle-class lifestyle and more and more common in all highly industrialized and mediated societies, is 
exposed and becomes audible. The article is accompanied by an audio file (12:50min), containing captured acoustic scenes from the three holidays. This includes background music at the reception, loud upbeat music at the pool, an entertainer at the buffet mixed with the sounds of other guests, and the ever-present humming backdrop of maintenance work and air-conditioning (the audio file can be accessed on our page at Seismograf: http://seismograf.org/fokus/out-of-space).

The chapter on gender in contemporary Nepali films by Dikshya Karki investigates the role of gender affirmation and transformation. While 'classical' topoi are often chosen, even in more recent mainstream films, they also allow for alterations of women roles - though, as Karki argues, not always with the consequence of challenging patriarchal hegemonic narratives. Though the films point towards changing gender roles, mainly through processes of urbanization (even of villages), migration and education, they ultimately still force those women trying to get 'out of space' to remain tied to restrictions based on the normative separation of 'home' for female homemakers and the streets of the city for 'loitering' men. There is no equal participation of women in 'public space'; access is still regulated despite the fact that the films seem to gesture towards an oscillation and women's empowerment surfacing in different spatial presences.

In conversation with Holger Schulze, musician and curator Shanti Suki Osman lays out the manifold aspects of her performance "Voicing Up" that lays out, including an accompanying sound piece, the role of "women* musicians", of their voice, and how technology is used as a means of empowerment (an audio file of this piece is accessible on our page at Seismograf: http://seismograf.org/fokus/outof-space). Voicing $U p$ was created as short sound piece accompaniment to a performative presentation of research at "Sonic Cyberfeminisms" at Lincoln University in May 2017. Her interview-based research was a result of investigating how female* artists of colour working in electronic music in Berlin practice empowerment, survival and resistance. Composed as a basic collage and intentionally using sounds made available under creative commons zero license, the piece serves as an introduction or even summary of the thoughts and topics expressed in the performative presentation, and therefore by the interviewees. The piece begins and ends, respectively, with the sounds of the opening and the closing of a laptop and incorporates a dominant heartbeat which eventually gives way to a money counting machine. Voicing $U p$ interweaves sounds from two main narrative groupings: household appliances and hand-held tools. In this way, the piece offers a simple audio interpretation of the struggles faced by the artists Osman interviewed - including the lack of resources, acceptance and support, a desire to create new (digital) spaces in which to survive and work, and a growing sense of exhaustion. For the Out of Space conference, the research was presented in an informal, almost radio show format with interspersed songs. For this publication, the ideas are also presented in the format of a conversation with Holger Schulze.

Robert Stock discusses in his chapter "Musik-Filmische Teilhabekonstellationen als Partizipationsversprechen und situiertes Wissen in The Queen of Silence (2014) and And-Ek Ghes... (2016)" how the promise of participation is present in 
the two mentioned movies: The Queen of Silence (2014) from Agnieszka Zwiefka and And Ek-Ghes (2016) by Philip Scheffner and Colorado Velcu. Participation being in both of these cases indeed an indispensible prerequisite for cultural practices - even in the most illegitimate locations. With his focus on the representation of sonic personae and idiosyncratic sensory abilities between deaf culture and transcultural meshworks he lays out how a shared anthropology can be understood in the area of the sensible and the sensory.

In the chapter "Spuren der Heterotopie: Hören in Admiralty, Hongkong", musicologist Andrien Uetz explores and reflects the lasting traces and resonances of the now-historical Umbrella-protests in the cityscape of Hong Kong. Uetz expands on the manifold more intricate aspects that might or might not be audible in the audio recordings. He stresses the erratic, not actually linear meanings that can be found in these sonic traces. In his explorations, the cityscape emerges as a transformed environment that can be sensed and heard - yet it is not an actually visible transformation. Has the whole city then been transformed into a third space, in the sensibilities of those at least who lived and protested? (an audio file to this chapter can be found on the Seismograf page: http://seismograf.org/fokus/out-of-space).

This issue closes with an article by musicologist Sanne Krogh Groth and performance researcher Katrine Samson, the inventors of the format of the audio paper. In their article, they lay out the current practice of this new format as well as its brief history. Therefore, this article can serve on the one hand as an introduction and invitation to apply and to experiment with this new academic format of the audio paper; on the other hand, this chapter also discusses the audio paper in the role it serves in academic discourse with its established restrictions of legitimacy and aptness. The audio paper emerged out of a necessity for researchers to inhabit a location in academia that allows for the practices of listening and recording, of presenting and of scrutinizing sonic experiences and sound environments (various audio files to this piece are accessible on our page at Seismograf: http://seismograf. org/fokus/out-of-space).

We wish to express our deepest thanks and gratitude to a number of supporters, contributors and collaborators. Laila Abu-Er-Rub and Mhairi Montgomery supported us in organizing the conference and editing. Thanks also go to the Cluster of Excellence "Asia and Europe in a Global Context" at the Ruprecht-Karls-University, Heidelberg, for co-funding the journal and the conference in Copenhagen that preceded the volume. We thank Christoph Wulf for his support in making this special issue happen. We thank the team at Seismograf in Copenhagen for hosting the selected audio papers as part of their magazine. Finally, we would like to thank the Department for Arts and Cultural Studies at the University of Copenhagen and the Sound Studies Lab for the financial, logistic, and general support of the conference in 2017.

Heidelberg/Copenhagen, Spring 2019 Christiane Brosius and Holger Schulze 


\section{References}

Augé, M. (1992): Non-Spaces. Introduction to an Anthropology of Supermodernity. New York: Verso.

Bhabha, H. K. (2004): The Location of Culture. Abingdon: Routledge.

Blesser, B./Salter, L.R. (2006): Spaces Speak, Are You Listening? Experiencing Aural Architecture. Cambridge/Mass.: MIT-Press.

Bowie, D. (2013): “Where are we now?” In: Bowie, D., The Next Day. New York: Iso/Columbia Records, track 5.

Burghardt, D./Zirfas, J. (eds.) (2019): Pädagogische Heterotopien: Von A bis Z. Weinheim and Basel: Beltz Juventa.

Foucault, M. (1997): Of Other Spaces: Utopias and Heterotopias. New York: Routledge.

Groth, S. K./Samson, K. (2016): „Audio Papers: A Manifesto“. In: Seismograf-Special Issue „Fluid Sounds“, 30. August 2016. Online: http://seismograf.org/fokus/fluid-sounds/audio_paper_manifesto.

Hajer, M. A./Reijndorp, A. (2001): In Search of New Public Domain: Analysis and Strategy. Rotterdam: NAi Publishers.

Howes, D. (2006): Charting the Sensorial Revolution. In: The Senses and Society 1 (1): 113-28.

Hou, J. (ed.) (2010): Insurgent Public Space. Guerilla Urbanism and the Remaking of public Cities. London: Routledge.

Hou, J. (ed.) (2012): Transcultural Cities. Border-Crossing and Place-Making. London: Routledge.

Järviluoma, H./Uimonen, H./Vikman, N./Kytö, M. (2009): Acoustic Environments in Change: Introducing the Study of Six European Village Soundscapes in Transition. Tampere: TAMK University of Applied Sciences.

LaBelle, B. (2010): Acoustic Territories: Sound Culture and Everyday Life. New York: Bloomsbury.

McCann, E./Ward, K. (eds.) (2011): Mobile Urbanism. City and Policymaking in the Global Age. Minneapolis: University of Minnesota Press.

Mehrotra, R./Vera, F. (2017): Ephemeral Urbanism. In: Lepik, A. (ed.): Does Permanence Matter? Ephemeral Urbanism. Munich Architekturmuseum, pp. 8-25.

Schafer, R. M. (1977): The Tuning of the World. New York: Knopf.

Zardini, M. (ed.) (2006): Sense of the City. An Alternate Approach to Urbanism. Montreal: Lars Müller Publishers/Canadian Centre for Architecture. 